\title{
Pentafluorinated $\beta$-Hydroxy Ketone Synthesis via Lithium-Mediated Aldol Reaction
}

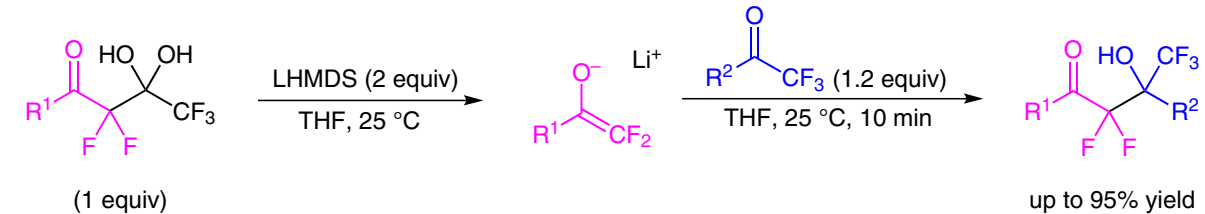

$\mathrm{R}^{1}=\mathrm{Ph}, 4-\mathrm{ClC}_{6} \mathrm{H}_{4}$, Naph, $\left(\mathrm{CH}_{2}\right)_{2} \mathrm{Ph}$

$\mathrm{R}^{2}=\mathrm{Ar}$, 2-thienyl, $\mathrm{Bn}$

Selected examples:<smiles>O=C(c1ccccc1)C(O)(C(F)(F)F)C(F)(F)c1ccc(Cl)cc1</smiles>

$94 \%$ yield<smiles>N#Cc1ccc(C(O)(C(F)(F)F)C(F)(F)C(=O)c2ccccc2)cc1</smiles>

$92 \%$ yield

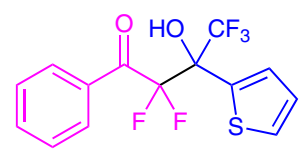

$83 \%$ yield<smiles>O=C(c1ccc(Cl)cc1)C(O)(C(F)(F)F)C(F)(F)C(F)(F)F</smiles>

$95 \%$ yield<smiles>CCOC(=O)c1ccc(C(O)(C(F)(F)F)C(F)(F)C(=O)c2ccccc2)cc1</smiles>

$95 \%$ yield<smiles>O=C(c1ccccc1)C(O)(Cc1ccccc1)C(F)(F)C(F)(F)F</smiles>

$63 \%$ yield<smiles>COc1ccc(C(O)(C(F)(F)F)C(F)(F)C(=O)c2ccccc2)cc1</smiles>

$93 \%$ yield<smiles>O=C(c1ccc2ccccc2c1)C(F)(F)C(O)(c1ccccc1)C(F)(F)F</smiles>

$93 \%$ yield<smiles>O=C(CCc1ccccc1)C(F)(F)C(O)(c1ccc(Cl)cc1)C(F)(F)F</smiles>

$84 \%$ yield
Significance: A fast and mild synthesis of pentafluorinated $\beta$-hydroxy ketones has been disclosed. The reaction proceeds via a lithium-promoted aldol reaction of readily available difluoroenolate precursors with trifluoromethyl ketones furnishing the corresponding pentafluorinated $\beta$-hydroxy ketones in good to excellent yield.
Comment: The described reaction is very versatile since it proceeds under ambient temperature and tolerates a broad range of functional groups. Furthermore, the authors show that the reduction of the pentafluorinated $\beta$-hydroxy ketones furnishes quantitatively the corresponding 1,3-diols favoring the syn-isomer. 